Indonesian Journal of Counseling \& Development p-ISSN: 2685-7375 | e-ISSN: 2685-7367

Vol. 02, No. 01, Juli 2020. pp. 19-24

\title{
THE EFFECT OF COPING STRATEGY ON ACADEMIC PROCRASTINATION IN COMPLETING STUDENT ASSIGNMENTS
}

\author{
Rauzatul Ulya ${ }^{1}$, Syaiful Indra ${ }^{2}$, Mahdi NK $^{3}$, Eko Sujadi ${ }^{4}$ \\ ${ }^{1}$ Program Studi Bimbingan dan Konseling Islam, Ar Raniry State Islamic University \\ ${ }^{2}$ Program Studi Bimbingan dan Konseling Pendidikan Islam, LAIN Kerinci \\ e-mail: syaiful.indra@ar-raniry.ac.id
}

\begin{abstract}
Terdapat dua faktor utama yang mempengaruhi prokrastinasi yaitu faktor internal dan eksternal. Faktor internal adalah faktor-faktor yang berasal dari individu yang turut membentuk prilaku prokrastinasi yang meliputi faktor fisik dan psikologis. Faktor eksternal yaitu faktor yang berasal dari luar individu dapat berupa tugas yang banyak (overloaded tasks) yang menuntut penyelesaian yang hampir bersamaaan. Hal ini diperparah apabila lingkungan mendukung prokrastinasi. Pelaku prokrastinasi (prokrastinator) cenderung melakukan prokrastinasi karena adanya rasa takut akan gagal, tidak suka pada tugas yang diberikan, menentang dan melawan kontrol, mempunyai sifat ketergantungan dan kesulitan membuat keputusan. Tujuan penelitian ini adalah untuk mengetahui strategi coping terhadap prokrastinasi akademik mahasiswa dalam menyelesaikan tugas perkuliahan. Pendekatan dalam penelitian ini adalah kuantitatif dengan jumlah responden 84 orang mahasiswa Bimbingan dan Konseling Islam angkatan 2016. Dalam penelitian ini mengunakan alat ukur berupa skala strategi coping dan skala prokrastinasi akademik dengan metode analisis regresi sederhana berganda dengan hasil koefisien korelasi problem focused coping yakni $-1,189$ dan $p=0,000(p<0,05)$. Sedangkan emotional focused coping yaitu $-089 p=0,611$ $(p>0,05)$. Problem focused coping Berpengaruh negatif artinya Semakin efektif penggunaan problem focused coping, maka prokrastinasi akademik semakin rendah. Sebaliknya apabila semakin tidak efektifnya penggunaan strategi problem focused coping, maka prokrastinasi akademik akan semakin tinggi. Koefisien determinasi menunjukkann problem focused coping secara simultan dapat menjelaskan perubahan prokrastinasi akademik sebesar $18,47 \%$.
\end{abstract}

Kata Kunci: Prokrastinasi akademik, Strategi Coping, Mahasiswa

\begin{abstract}
There are two main factors that influence procrastination, namely internal and external factors. Internal factors are originating from individuals who helped shape procrastination behavior which includes physical and psychological factors. External factors, namely factors originating from outside the individual can be in the form of many tasks (overloaded tasks) that require completion that is almost together. This is compounded if the environment supports procrastination. Actors of procrastination (procrastinators) tend to do procrastination because of the fear of failure, do not like the task given, oppose and fight control, have the nature of dependence and difficulty making decisions. The purpose of this study was to determine the coping strategies of student academic procrastination in completing lecture assignments. The approach in this study was quantitative with 84 respondents. Guidance and Counseling students of the class of 2016. In this study used a measuring tool in the form of a coping strategy scale and academic procrastination scale with a simple multiple regression analysis method with the results of the problem focused coping correlation coefficient ie $-1,189$ and $p=0,000(p<0.05)$. While emotional focused coping is -089 $p=0.611$ ( $p>0.05$ ). Problem focused coping Negatively affects the more effective the use of problem focused coping, the lower the academic procrastination. Conversely, if the more ineffective use of problem focused coping strategies, the academic procrastination will be higher. The coefficient of determination shows that problem focused coping can simultaneously explain changes in academic procrastination of $18.47 \%$.
\end{abstract}

Keywords: Academic Procrastination, Coping Strategies, Students 


\section{INTRODUCTION}

Youth or students are often referred to as agents of change in a nation (Salam, 2004). Students as the hope of the nation are expected to be able to change conditions and make changes in society towards a better direction which can then improve a more prosperous standard of living. All of that can be realized of course by studying and studying. The spirit of a person in seeking knowledge is certainly based on how much he understands what knowledge is, and what are the virtues in studying. Imam Al-Ghazali explained that with human knowledge, we know which way to climb, and how to climb it, know how to get through obstacles and obstacles that cross the road.

Educational Institutions, one of them is the State Islamic University is an institution that gives birth to individuals who are competent in the field of science and also competent in the field of religious science. Especially at the level of the Faculty of Da'wah and Communication at the Ar-Raniry State Islamic University. The Faculty of Da'wah and Communication has a vision and mission in producing students who have high skills and dedication.

The Faculty of Da'wah and Communication has improved quality standards in accordance with the standards of the National Education System. At least in general the organization of Higher Education has the aim of graduating prospective scholars in a professional and timely manner in completing their studies. So the target set is quite rational, that $90 \%$ of students are able to complete their studies on time, which is for eight semesters. In reality, these conditions turned out to be very difficult to realize. Based on the survey results of researchers, in the Faculty of Da'wah and Communication in the 2016/2017 school year students who completed their studies on time ( 7 to 8 semesters) only reached $70 \%$. This is very unfortunate. This situation occurs due to several factors that influence, such as the environment, friends,

Based on observations made by researchers on May 2, 2019 at the Academic Faculty of Da'wah and Communication UIN Ar-Raniry about the alumni data of Islamic Guidance and Counseling study program at the Da'wah Faculty, researchers found data that there are still many students who have not finished on time 8 or 9 semesters with various One of the factors is academic procrastination, unfinished courses and courses that must be repeated because they get bad grades from lecturers who care for the subjects (Academic Data of UIN Ar Raniry UIN, 2018-2019).

Procrastination that occurs among students due to the lack of coping strategies in completing lecture assignments, students often buy time to complete lecture assignments given by lecturers. 
Individuals who procrastinate are aware that they are facing important tasks. However, deliberately procrastinating repeatedly so that the feeling of discomfort, anxiety, and feeling guilty in him appears (Gufron \& Risnawita, 2010). Individuals more often procrastinate on academic assignments, preferring other activities that can satisfy themselves so as to suspend assignments until near the deadline for collection. Therefore, researchers are interested in examining the effect of Coping Strategies on Academic Procrastination in Completing Lecture Tasks in Islamic Counseling Students of the Da'wah and Communication Faculty of UIN Ar-Raniry Banda Aceh.

\section{METHOD}

This type of research used in this study is the type of correlational research, which is looking at the relationship between the variables studied. This type of research aims to determine between one variable influencing other variables expressed by the magnitude of the correlation coefficient (bivariate) and significance (significance) statistically (Hamdi, 2014). Data collection methods used are the scale of coping and procurement in the form of a Likert scale. The sample of this study were 84 Islamic Guidance and Counseling students from the 2016 class using probablity sampling techniques.

\section{THE RESULTS}

Based on the results of the study showed that the coping strategy in the form of problem focused coping had a negative effect on the academic procrastination of students in completing lecture assignments, evidenced by $\mathrm{t}$ arithmetic $=-3,869$ greater than $\mathrm{t}$ table $=1,989(-3,869>1,989)$ with a significance level of $0,000(\mathrm{p}<0.05)$. This shows that the first hypothesis in this study Ha was accepted and $\mathrm{H} 0$ was rejected. Effective contribution of 18.47 , this shows that $18.47 \%$ of the contribution of coping strategies in the form of problem focused coping on student academic procrastination.

While the coping strategy in the form of emotional focused coping has no effect on academic procrastination as evidenced by $\mathrm{t}$ arithmetic $=-511$ greater than $\mathrm{t}$ table $=1.989(-511$ $<1.989$ ) with a significance level of 0.611 . By using the significance limit is greater than $5 \%$ level which means that $\mathrm{HO}$ is accepted and $\mathrm{Ha}$ is rejected. Thus, the second hypothesis of this study is not proven, it means that there is no significant effect of emotional focused coping on academic procrastination. 
According toNur Gufron \& Rini Risnawita (2010), someone who has a tendency to postpone or not immediately start work, when starting work and tasks is called someone who does procrastination. It doesn't matter whether the delay has a reason or not. Every delay in dealing with a task is called procrastination.

Factors that influence procrastination are problem focused coping. The results of research conducted by Hendi Syarkiki and Jati Ariatithere is significant relationship between problem focused coping with academic procrastination. Lazarus \& Folkman said that workrelated problems are often overcome by problem focused coping while health problems use emotional focused coping (Sarafino \& Smith, 2011). Problem focused coping helps individuals deal with stress by finding useful information, whereas emotion focused coping focuses on emotions that do not eliminate stressors or do not help individuals in developing better ways to manage stressors (Nevid, Rathus, \& Greene)

Lazarus and Folkman (Smet, 1994) say that problem focused coping is more often used by individuals who feel confident that they can change a situation or deal with demands that can still be controlled. Students who have confidence that they are able to overcome problems in doing academic work will take appropriate action. One factor that influences problem focused coping is the type of education. The results of research conducted by Rizki, Kuncoro, and Supradewi (2008) show a relationship between spiritual intelligence and problem focused coping. Problem focused coping tends to be used by individuals who have a good level of spiritual intelligence. The results also showed that the effective contribution of problem focused coping was $18.47 \%$ in academic procrastination. These conditions state that the consistency level of the academic procrastination variable $18.47 \%$ can be predicted by the problem focused coping variable, the remaining $71.53 \%$ is determined by other factors such as religiosity and academic procrastination research conducted by Hayinah the effective contribution of $55.95 \%$. Other studies are the relationship of self-efficacy and academic procrastination in completing students lecture work done by Damri, Engkizar and Fuady Anwar were effective contributions of 23.8\%.

The results of this study indicate that there is a negative influence between coping strategies with procrastination with $\beta$ (problem focused coping) $=-0,419$ and $\mathrm{t}$ arithmetic $=-3,869$ and $\mathrm{p}=$ 0,000 means that the more effective the coping strategy, the lower the academic procrastination of Islamic Guidance and Counseling students conversely the less effective coping strategies, the more academic procrastination of students rises. This is supported by Risda's research entitled the effect of coping and time management strategies on academic procrastination in the midwifery students of the Ministry of Health, East Kalimantan, where the results show that the contribution of coping and time management strategies to academic procrastination was $86.9 \%$ (Risda, 2018). 
Academic procrastination on students needs to be alleviated and preventive measures taken that can help students minimize the attitude of procrastination that can harm themselves by conducting coping strategies. Coping can be interpreted as an individual way to overcome the pressure of the problem, in coping individuals differ in overcoming the problem some tend to choose problem focused coping and some others choose emotional focused coping.

In this study, researchers found interesting facts, namely in the coping strategy there are two forms of strategy, the first strategy focused coping strategy and the second is emotional focused coping, where both of these strategies have different results after conducting research that the problem focused coping has an influence on academic procrastination with $\mathrm{p}$ value 0,000 $<0.05$ while emotional focused coping with $\mathrm{p}$ value $0.611>0.05$. So it can be concluded that what plays a role in the coping strategy against procrastination is problem focused coping.

This research has also succeeded in finding out the categories of student academic procrastination, based on the results of the overall analysis the level of academic procrastination of students is only in the medium category that is equal to $70.23 \%$. The medium category means that most students still exhibit procrastination in starting to do lecture assignments, causing delays in completing lecture assignments.

Based on the description above it can be concluded that the coping strategy there are two forms of coping namely problem focused coping (coping centered on problem solving) and emotional focused coping (coping centered on emotions). This study shows that problem focused coping which has a negative role on student academic procrastination in completing lectures is $18.47 \%$ while the remaining 81.53 is influenced by other factors.

\section{CONCLUSION}

Based on research results from the two forms of coping strategies that most influence on academic procrastination is problem focused coping with an effective contribution of $18.47 \%$ with a significance level of 0,000 while emotional focused coping has no significant effect on procrastination.

\section{REFERENCE}

Ali Gunawan, Statistik Penelitian Bidang Pendidikan, Psikologi dan Sosial, (Parama Publishing, Yogyakarta, 2015).

Al-Qur'an tajwid dan terjemahan. Kementrian Agama RI, Sygma Exagrafika.2007

Arikunto, Suharsimi. Prosedur Penelitian, Suatu Pengantar Praktik Edisi IV. ( Jakarta Rineka Cipta 2006). 
Asep Saepul Hamdi, Metode Penelitian Kuantitatif Aplikasi Dalam Pendidikan, (Yogyakarta, CV. Budi utama, 2014).

Atkinson, Rita, L., "Introduction to Psycology, Terjemahan Pengantar Psikologi Edisi Kesebelas, jilid 2", Wijayanti Kusuma 1993 (Jakarta: Interaksana).

Azwar Saifuddin, Metode Penelitian. (Yogyakarta Pustaka Pelajar ,2009).

Billings, A. G. \& Moos, R. H. 1984. Coping, Stress, and Social Resources Among Adults with Unipolar Depression. Journal of Personality and Social Psychology. Vol. 46.

Burka \& Yuen, Procrastination, Why You Do Tt What to Do About It Now, (New York: Perseus Books Group, 2008).

Gufron \& Rini Risnawita S. “Teori-Teori Psikologi”, (Yogyakarta, Ar-Ruzz Media, 2010).

Indra, S. (2016). Efektivitas Team Assisted Individualization untuk Mengurangi Prokrastinasi Akademik. Jurnal Edukasi: Jurnal Bimbingan Konseling, 1(2), 175-189

Indra, S., Rapono, M., \& Hayati, R. (2018). Efektivitas team Assisted Individualization untuk Meningkatkan Pemahaman pada Mata Kuliah Model-Model Konseling. Jurnal Penelitian Pendidikan Sosial Humaniora, 2(1), 141-146

Julia, H., Jarnawi, J., \& Indra, S. (2019). Pola Pengasuhan Pada Konteks Kematangan Emosional Ibu Single Parent. Indonesian Journal of Counseling and Development, 1(1), 31-49

Pohan, RA Pohan., \& Indra, S. (2020) Efektivitas Layanan Bimbingan Kelompok dalam Meningkatkan Kegiatan Merespon Pembelajaran. Islamic Counseling: Jurnal Bimbingan Konseling Islam, 4(1), 17-30

Richard S, Lazarus dan Susan Folkman, "Stres Appraisal and Coping" (New York, Spinger Publishing Company, 1984).

Sujadi, E. (2015). Konseling Pancawaskita untuk Membentuk Problem Focused Coping. Jurnal Konseling Dan Pendidikan, 3(1), 14-24. https://doi.org/https://doi.org/10.29210/112100

Sujadi, E. (2018). Kode Etik Profesi Konseling Serta Permasalahan dalam Penerapannya. Tarbawi: Jurnal Ilmu Pendidikan, 14(2), 69-77. https://doi.org/10.32939/tarbawi.v14i2.298

Sujadi, E. (2019). Penerapan Play Therapy dengan Menggunakan Permainan Tradisional untuk Meningkatkan Keterampilan Sosio Emosional. Jurnal Bimbingan Dan Konseling Terapan, 3(1), 14-24. https://doi.org/http://dx.doi.org/10.30598/jbkt.v3i1.892

Sujadi, E., Meditamar, M. O., Ahmad, B., \& Rahayu, A. (2018). Pengaruh Konsep Diri dan Locus of Control Terhadap Motivasi Berprestasi. Educational Guidance and Counseling Development Journal, 1(1), 32-51. https://doi.org/http://dx.doi.org/10.24014/egcdj.v1i1.4808

Sujadi, E., \& Setioningsih, L. (2018). Perbedaan Locus Of Control Ditinjau dari Etnis. Jurnal Bimbingan Dan Konseling Terapan, 2(2), 128-138. https://doi.org/http://dx.doi.org/10.30598/jbkt.v2i2.371 